\title{
SEQUENTIAL EXTRACTION OF PHOSPHORUS BY MEHLICH-1 AND ION EXCHANGE RESIN FROM B HORIZONS OF FERRIC AND PERFERRIC LATOSOLS (OXISOLS)
}

\author{
Danilo de Lima Camêlo ${ }^{(1) *}$, João Carlos $\operatorname{Ker}^{(2)}$, Roberto Ferreira Novais ${ }^{(3)}$, Marcelo Metri \\ Corrêa $^{(4)}$ and Vinício Coelho de Lima ${ }^{(5)}$
}

\footnotetext{
(1) Universidade de São Paulo, Escola Superior de Agricultura "Luiz de Queiroz", Departamento de Ciência do Solo, Programa de Pós-graduação em Ciência do Solo, Piracicaba, São Paulo, Brasil.

(2) Universidade Federal de Viçosa, Departamento de Solos, Viçosa, Minas Gerais, Brasil.

(3) Universidade Federal de Viçosa, Instituto de Ciências Agrárias, Campus de Rio Paranaíba, Rio Paranaíba, Minas Gerais, Brasil.

(4) Universidade Federal Rural de Pernambuco, Unidade Acadêmica de Garanhuns, Garanhuns, Pernambuco, Brasil.

(5) Universidade Federal de Viçosa, Curso de Geografia, Viçosa, Minas Gerais, Brasil.

* Corresponding author.

E-mail: danilocamelo@agronomo.eng.br
}

\begin{abstract}
In general, Latosols have low levels of available $P$, however, the influence of the parent material seems to be decisive in defining the pool and predominant form of $P$ in these soils. This study evaluated $P$ availability by extraction with Mehlich-1 (M-1) and Ion Exchange Resin (IER), from samples of $B$ horizons of Ferric and Perferric Latosols developed from different parent materials. To this end, in addition to the physical and chemical characterization of soils, 10 sequential extractions were performed with M-1 and IER from samples of $B$ horizons (depth between 0.8 and $1.0 \mathrm{~m}$ ). Total contents of $\mathrm{Ca}, \mathrm{P}, \mathrm{Fe}, \mathrm{Al}$, and $\mathrm{Ti}$ were determined after digestion with nitric, hydrofluoric and perchloric acids. The effects of sequential $P$ extractions on Fe oxides were also evaluated from the analyses of dithionite-citrate-bicarbonate and ammonium acid oxalate. The high similarity between contents of $P$ accumulated after sequential extractions with M-1 and IER in soils developed on tuffite indicated a predominance of P-Ca. Higher contents of $P$ after a single IER extraction show greater efficiency in $P$ removal from highly weathered soils, as from the Latosols studied here. The $P$ contents also show the high sensitivity of extractant M-1 in highly buffered soils. Furthermore, a single extraction with extractant M-1 or IER is not sufficient to estimate the amount of labile $P$ in these soils.
\end{abstract}

Keywords: labile phosphorus, iron oxyhydroxides, tuffite, mafic rocks, total digestion. 


\title{
RESUMO: EXTRAÇÕES SEQUENCIAIS DE FÓSFORO POR MEHLICH-1 E RESINA DE TROCA IÔNICA EM HORIZONTES B LATOSSÓLICOS FÉRRICOS E PERFÉRRICOS
}

\begin{abstract}
Os Latossolos apresentam, de modo geral, baixos teores de P disponível; no entanto, a influência do material de origem parece ser decisiva na definição do estoque e da forma de P predominante nesses solos. O objetivo deste trabalho foi avaliar a disponibilidade de P, pelos extratores Mehlich-1 (M-1) e Resina de Troca Iônica (RTI), em amostras de horizontes B de Latossolos Férricos e Perférricos desenvolvidos a partir de diferentes materiais de origem. Para tanto, além da caracterização física e química dos solos, foram realizadas 10 extrações sequenciais com os extratores $M-1$ e RTI em amostras de horizonte $B$ coletadas entre 0,8 e 1,0 m de profundidade. Os teores totais de Ca, $\mathrm{P}, \mathrm{Fe}$, Al e Ti foram determinados após digestão com os ácidos nítrico, fluorídrico e perclórico. Os efeitos das extrações sequenciais de $P$ sobre os óxidos de Fe também foram avaliados a partir das análises com ditionito-citrato-bicarbonato e oxalato ácido de amônio. A maior semelhança observada entre os teores de P acumulado após as extrações sequenciais com M-1 e RTI nos solos desenvolvidos de tufito é indicativo da predominância de P-Ca. Os maiores teores de P extraídos pela RTI após uma única extração relevam sua maior eficiência na remoção de $P$ em solos bastante intemperizados como os Latossolos estudados e, ainda, ressalta a elevada sensibilidade do extrator $M-1$ em solos altamente tamponados. Além disso, uma única extração com o extrator M-1 ou RTI não é suficiente para estimar o fator quantidade de P lábil nesses solos.
\end{abstract}

Palavras-chave: fósforo lábil, oxihidróxidos de ferro, tufito, rochas máficas, digestão total.

\section{INTRODUCTION}

Although $\mathrm{P}$ is a macronutrient required by plants in smaller quantities, it is often the main limiting factor of agricultural production in Brazil (Raij, 1991). Tropical soils are typically P-deficient, due to interactions of the element with mineral constituents of the soil. The term $\mathrm{P}$ sorption refers to the phenomena of adsorption on mineral surfaces and precipitation in less soluble form, which commonly occurs in tropical acidic soils that are rich in $\mathrm{Fe}$ and $\mathrm{Al}$ oxyhydroxides, such as Latosols in general (Motta et al., 2002).

The intensity of sorption processes depends mainly on the clay content and nature in soils (Bahia Filho et al., 1983; Valladares et al., 2003). Thus, predominantly oxidic soils with higher clay content have higher $\mathrm{P}$ adsorption and more $\mathrm{Fe}$ and Al-associated P forms than soils with kaolinitic mineralogy (Ker, 1995; Motta et al., 2002). In this sense, oxyhydroxide $\mathrm{Fe}$ and $\mathrm{Al}$ minerals are the most active components in the clay fraction for $\mathrm{P}$ adsorption, and the minerals goethite and gibbsite are mainly responsible for this phenomenon in Latosols (Bahia Filho et al., 1983; Ker, 1995; Fontes and Weed, 1996; Rolim Neto et al., 2004).

Crops also influence $\mathrm{P}$ adsorption in different ways. Motta et al. (2002) found increased contents of Ca-associated $\mathrm{P}$ forms in cultivated soils with annual phosphate fertilization and occasional liming. A number of effects could be contributing to the reduction of $\mathrm{P}$ adsorption and increased P-Ca contents (Motta et al., 2002): liming, affecting the reduction of positive charges and organic matter decomposition, generating lower molecular weight compounds that compete with $\mathrm{P}$ for exchange sites, and/or even longstanding phosphate fertilization, promoting the removal of part of the elements in solution ( $\mathrm{Ca}, \mathrm{Fe}$ and $\mathrm{Al})$ by precipitation with $\mathrm{P}$.

When determining the potentially plant-available $\mathrm{P}$ content, some authors (Campello et al., 1994; Gatiboni et al., 2002; Rheinheimer et al., 2003) detected significant variations between the contents obtained in a single extraction and in several successive steps with the same extractant. In highly weathered and buffered soils, the values obtained in a single extraction are obviously underestimated, since various energy interaction levels with inorganic colloids, as well as extractant wear, affect the ability of some prediction methods (Gatiboni et al., 2002; Novais et al., 2007; Freitas et al., 2013). Variations in contents of available $\mathrm{P}$ can also be a consequence of the predominant form, determining the $\mathrm{P}$ contents in weathered soils (Souza Júnior et al., 2012).

Soil laboratories in Brazil use the extractants Mehlich-1 (M-1) and Ion Exchange Resin (IER) as main quantification methods of soil $\mathrm{P}$ supply (Silva and Raij, 1999). M-1 is a diluted mixture of hydrochloric and sulfuric acids, and $\mathrm{P}$ extraction occurs through exchange of ligands in which the adsorbed phosphate anion is replaced by the $\mathrm{SO}_{4}^{2-}$ anion, conjugate base of sulfuric acid. However, in clayey soils, mainly with higher $\mathrm{pH}$, the $\mathrm{P}$ extraction power is compromised, because in addition to a rapid $\mathrm{pH}$ increase in the extracting solution in contact with the soil, the $\mathrm{SO}_{4}^{2-}$ anion can be adsorbed at sites so far unoccupied by $\mathrm{P}$, resulting in a phenomenon called extractant wear (Novais et al., 2007).

Ion exchange resin consists of positively and negatively charged organic polymers, whose 
desorption process of labile $\mathrm{P}$ is induced by a concentration imbalance between the solution and the soil solid phase. Therefore, Silva and Raij (1999) consider its use suitable to estimate the capacity of $\mathrm{P}$ supply of the soil because the extraction process resembles the action of plant roots, which would reduce the extractant sensitivity (wear) in soils with high clay content. However, $\mathrm{P}$ contents extracted by IER from soils with pronounced P-Ca forms, are similar to those obtained by $\mathrm{M}-1$, given the Ca-drain effect of cationic resin that intensifies $\mathrm{P}$ solubilization, which does not occur with anionic resin alone (Freitas et al., 2013). Souza Júnior et al. (2012) reported similarity between the behavior of extractants M-1 and IER in very clayey and buffered soils, treated with Gafsa phosphate, a condition in which the extractant M-1 tends to wear out.

This study assessed $\mathrm{P}$ availability by extraction with M-1 and IER, in B horizon samples of Ferric and Perferric Latosols developed from different parent materials.

\section{MATERIAL AND METHODS}

The study was conducted in the laboratory of the Soil Department of the Federal University of Viçosa at room temperature. Samples of B horizons of 13 Latossolos Vermelhos ferric and perferric and of one Latossolo Vermelho-Amarelo mesoferric developed from different parent materials were collected between 0.8 and $1.0 \mathrm{~m}$ deep, in different regions of the State of Minas Gerais, Brazil. The sampling sites with pronounced influence of parent materials were based on the soil map of the State of Minas Gerais. We sampled soils in the region of the Triângulo Mineiro, developed from basalt $\left(\mathrm{LV}_{1}, \mathrm{LV}_{2}, \mathrm{LV}_{3}\right.$, and $\mathrm{LV}_{4}$ ), in the Alto Paranaíba region, originated from tuffite or under tuffite influence $\left(\mathrm{LV}_{5}, \mathrm{LV}_{6}, \mathrm{LV}_{7}, \mathrm{LV}_{8}\right.$, $\mathrm{LV}_{9}, \mathrm{LV}_{10}$, and $\mathrm{LVA}_{1}$ ), in the metropolitan region of Belo Horizonte, derivatives of itabirite $\left(\mathrm{LV}_{11}\right)$ and amphibolite $\left(\mathrm{LV}_{12}\right)$, and in the region of Campo das Vertentes, formed from gabbro $\left(\mathrm{LV}_{13}\right)$.

To show the effect of the parent materials on $\mathrm{P}$ contents in the soil, we decided to use subsurface horizons (B Latosols), with no initial $\mathrm{P}$ source supply. In this way, we minimized the influence of management (phosphate fertilization and liming), since $\mathrm{P}$ has low mobility in oxidic soils, such as Latosols (Novais and Smyth, 1999; Donagemma et al., 2008).

To perform the analyses, samples were used as air-dried fine earth (ADFE), obtained by air-drying, crumbling and sieving $(<2 \mathrm{~mm})$.

In the chemical and physical analyses of soil samples (Table 1), we determined $\mathrm{pH}$ in water and solution with $\mathrm{KCl}$ (ratio 1:2.5); exchangeable $\mathrm{Ca}^{2+}, \mathrm{Mg}^{2+}$ and $\mathrm{Al}^{3+}$, by extraction with $\mathrm{KCl} 1 \mathrm{~mol} \mathrm{~L}^{-1}$; potential acidity $(\mathrm{H}+\mathrm{Al})$ by titrations after extraction with $0.5 \mathrm{~mol} \mathrm{~L}^{-1}$ calcium acetate at $\mathrm{pH}$ 7.0; available $\mathrm{P}$ and $\mathrm{K}$ after extraction with $0.05 \mathrm{~mol} \mathrm{~L}^{-1} \mathrm{HCl}$ solution and $0.025 \mathrm{~mol} \mathrm{~L}^{-1}$ $\mathrm{H}_{2} \mathrm{SO}_{4}$ (M-1) (Embrapa, 2011); and remaining $\mathrm{P}$ (P-rem) by determining the $\mathrm{P}$ balance solution after shaking ADFE for $1 \mathrm{~h}$ with $0.01 \mathrm{~mol} \mathrm{~L}^{-1} \mathrm{CaCl}_{2}$ solution containing $60 \mathrm{mg} \mathrm{L}^{-1}$ of $\mathrm{P}$ at a $1: 10$ soil solution ratio (Alvarez $\mathrm{V}$ et al., 2000). The $\mathrm{Ca}^{2+}, \mathrm{Mg}^{2+}$ and $\mathrm{Al}^{3+}$ contents were determined by atomic absorption spectrophotometry, $\mathrm{P}$ by colorimetry (Braga and Defelipo, 1974), K by flame photometry, and total organic carbon (TOC) by the Walkley-Black method (Embrapa, 2011). The $\mathrm{Ki}$ and $\mathrm{Kr}$ indexes were estimated from the analysis of sulphuric digestion (ratio 1:1) in ADFE fraction, and the $\mathrm{Si}, \mathrm{Al}$ and $\mathrm{Fe}$ contents used to calculate the relations were quantified by plasma optical emission spectroscopy (Embrapa, 2011). Particle size analysis was performed according to Embrapa (2011).

The total contents of $\mathrm{Ca}, \mathrm{P}, \mathrm{Fe}, \mathrm{Al}$ and Ti were determined by plasma optical emission spectroscopy, after total digestion of ADFE with a ternary mixture of concentrated nitric, hydrofluoric and perchloric acids, according to Embrapa (2011).

Available $\mathrm{P}$ contents were determined after 10 successive extractions by IER (50\% resin Amberlite IRA-400 + 50 \% resin Amberlite IR-120) saturated with sodium bicarbonate (Raij and Quaggio, 2001) and by the extraction method M-1 $\left(0.05 \mathrm{~mol} \mathrm{~L}^{-1} \mathrm{HCl}+0.025 \mathrm{~mol} \mathrm{~L}^{-1} \mathrm{H}_{2} \mathrm{SO}_{4}\right)$.

For $\mathrm{P}$ determination in soil by IER extractions, $2.5 \mathrm{~cm}^{3}$ soil was placed in a conical plastic recipient of $80 \mathrm{~mL}$, along with $25 \mathrm{~mL}$ of deionized water and a medium-sized glass sphere, and shaken in a horizontal device for $15 \mathrm{~min}$ at $220 \mathrm{rpm}$. Then the glass sphere was removed and $2.5 \mathrm{~cm}^{3}$ of IER, previously treated with $1 \mathrm{~mol} \mathrm{~L}^{-1} \mathrm{NaHCO}_{3}$ at $\mathrm{pH}$ 8.5, was added. Next, the mixture containing IER with deionized water was subjected to horizontal shaking for $16 \mathrm{~h}$ at $220 \mathrm{rpm}$. Subsequently, IER was separated from the soil using a polyester sieve (0.4 mm mesh) applying jets of deionized water to wash the retained material. The suspension with soil was transferred again to the plastic containers for subsequent extractions, the $\mathrm{pH}$ adjusted to 6.0 with a solution of $0.1 \mathrm{~mol} \mathrm{~L}^{-1} \mathrm{HCl}$ to promote flocculation, and the suspension was left to stand for $36 \mathrm{~h}$ between one extraction and another. The IER retained in the sieve was transferred individually to $100 \mathrm{~mL}$ flasks and $50 \mathrm{~mL}$ of a solution with $0.8 \mathrm{~mol} \mathrm{~L}^{-1} \mathrm{NH}_{4} \mathrm{Cl}$ and $0.2 \mathrm{~mol} \mathrm{~L}^{-1}$ $\mathrm{HCl}$ was added and left to stand for $30 \mathrm{~min}$ to eliminate $\mathrm{CO}_{2}$. Thereafter, the flasks were closed and subjected to horizontal circular shaking for $1 \mathrm{~h}$ at $220 \mathrm{rpm}$. $\mathrm{P}$ concentration in the extracted 
Table 1. Physical and chemical properties of the B horizonts of Latossolos Vermelhos ferric and perferric and Latossolo Vermelho-Amarelo mesoferric

\begin{tabular}{|c|c|c|c|c|c|c|c|c|c|c|c|c|c|c|}
\hline Pro & $\mathrm{LV}_{1}$ & $\mathrm{LV}_{2}$ & $\mathrm{LV}_{3}$ & $\mathrm{LV}_{4}$ & $\mathrm{LV}_{5}$ & $\mathrm{LV}_{6}$ & $\mathbf{L V}_{7}$ & $\mathrm{LV}_{8}$ & $\mathrm{LV}_{9}$ & $\mathrm{LV}_{10}$ & $\mathrm{LV}_{11}$ & $\mathrm{LV}_{12}$ & $\mathrm{LV}_{13}$ & $\mathrm{VA}_{1}$ \\
\hline $\mathrm{pH}\left(\mathrm{H}_{2} \mathrm{O}\right)$ & 8 & 5.88 & 5.68 & 47 & 57 & 02 & 30 & .76 & 39 & .17 & 76 & 1.96 & .70 & 4.89 \\
\hline $\mathrm{pH}(\mathrm{KCl})$ & 4.85 & 5.90 & 5.23 & 5.33 & 5.53 & 4.37 & 4.86 & 5.39 & 5.27 & 4.53 & 5.29 & 4.26 & 6.33 & 5.40 \\
\hline$\Delta \mathrm{pH}$ & -1.33 & 0.02 & -0.45 & -0.14 & -0.04 & -0.65 & -0.44 & -0.37 & -0.62 & -0.64 & -0.47 & -0.70 & 0.63 & 0.51 \\
\hline $\mathrm{OC}\left(\mathrm{g} \mathrm{kg}^{-1}\right)^{(1)}$ & 8.4 & 8.4 & 10.7 & 11.5 & 12.2 & 29.0 & 9.2 & 7.7 & 8.4 & 23.7 & 13.0 & 35.9 & 10.5 & 14.2 \\
\hline $\mathrm{P}\left(\mathrm{mg} \mathrm{dm}^{-3}\right)$ & 1.1 & 0.3 & 0.2 & 5 & 0.0 & 6.5 & 6.5 & 2.0 & 37.5 & 17.5 & 0.5 & 1.1 & 1.2 & 0.6 \\
\hline Prem $\left(\mathrm{mg} \mathrm{L}^{-1}\right)^{(2)}$ & 2.1 & 0.7 & 1.8 & 2.0 & 1.7 & 3.9 & 3.9 & 0.9 & 4.0 & 3.0 & 2.4 & 8.4 & 5.5 & 4.0 \\
\hline $\mathrm{K}\left(\mathrm{mg} \mathrm{dm} \mathrm{m}^{-3}\right)$ & 15.0 & 1.0 & 3.0 & .0 & 5.0 & 1.0 & 3.0 & 5.0 & 2.0 & 8.0 & 1.0 & 16.0 & 12.0 & 11.0 \\
\hline $\mathrm{Ca}^{2+}\left(\mathrm{cmol}_{\mathrm{c}} \mathrm{dm}^{-3}\right)$ & 0.36 & 0.13 & 0.35 & 0.15 & 0.05 & 0.05 & 0.20 & 0.11 & 0.72 & 0.09 & 0.06 & 0.12 & 0.07 & 0.00 \\
\hline $\mathrm{Mg}^{2+}\left(\mathrm{cmol}_{\mathrm{c}} \mathrm{dm}^{-3}\right)$ & 0.50 & 0.00 & 0.01 & 0.01 & 0.03 & 0.00 & 0.00 & 0.08 & 0.04 & 0.01 & 0.00 & 0.01 & 0.20 & 0.00 \\
\hline $\mathrm{Al}^{3+}\left(\mathrm{cmol}_{\mathrm{c}} \mathrm{dm}^{-3}\right)$ & 0.00 & 0.00 & 0.00 & 0.00 & 0.00 & 0.59 & 0.00 & 0.00 & 0.00 & 0.39 & 0.00 & 0.49 & 0.00 & 0.00 \\
\hline $\mathrm{H}+\mathrm{Al}\left(\mathrm{cmol}_{\mathrm{c}} \mathrm{dm}^{-3}\right)$ & 3.70 & 2.10 & 3.20 & 3.50 & 3.20 & 10.90 & 5.20 & 3.40 & 6.10 & 8.20 & 4.20 & 11.10 & 3.50 & 8.70 \\
\hline $\mathrm{m}(\%)^{(3)}$ & 0.0 & 0.0 & 0.0 & 0.0 & 0.0 & 92.2 & 0.0 & 0.0 & 0.0 & 76.5 & 0.0 & 74.2 & 0.0 & 0.0 \\
\hline $\mathrm{SB}\left(\mathrm{cmol}_{\mathrm{c}} \mathrm{dm}^{-3}\right)^{(4)}$ & 70 & 0 . & 0.37 & 0.18 & 0.09 & 0.05 & 0.21 & 0.20 & 0.77 & 0.12 & 0.06 & 0.17 & 0.30 & 0.03 \\
\hline $\mathrm{V}(\%)^{(5)}$ & 15.9 & 5.8 & 10.4 & 4.9 & 2.7 & 0.5 & 3.9 & 5.6 & 11.2 & 1.4 & 1.4 & 1.5 & 7.9 & 0.3 \\
\hline $\mathrm{CEC}_{\mathrm{e}}\left(\mathrm{cmol}_{\mathrm{c}} \mathrm{dm}^{-3}\right)$ & 0.70 & 0.13 & 0.37 & 10 & 0.09 & 0.64 & 0.21 & 0.20 & 0.77 & 0.51 & 0.06 & 0.66 & 0.30 & 0.03 \\
\hline $\mathrm{CEC}_{7,0}\left(\mathrm{cmol}_{\mathrm{c}} \mathrm{dm}^{-3}\right)$ & 4.40 & 2.23 & 3.57 & 3.68 & 3.29 & 10.95 & 5.41 & 3.60 & 6.87 & 8.32 & 4.26 & 11.27 & 3.80 & 8.73 \\
\hline Index $\mathrm{Ki}^{(6)}$ & 1.54 & 0.46 & 0.61 & 0.36 & 0.24 & 0.71 & 0.24 & 0.40 & 0.36 & 0.65 & 0.13 & 0.74 & 0.70 & 0.42 \\
\hline Index $\mathrm{Kr}^{(7)}$ & 0.81 & 0.27 & 0.34 & 0.20 & 0.16 & 0.48 & 0.09 & 0.21 & 0.13 & 0.31 & 0.03 & 0.42 & 0.45 & 0.33 \\
\hline Coarse sand $\left(\mathrm{g} \mathrm{kg}^{-1}\right)$ & 20 & 30 & 30 & 40 & 70 & 60 & 60 & 60 & 0 & 80 & 320 & 70 & 110 & 60 \\
\hline Fine sand $\left(\mathrm{g} \mathrm{kg}^{-1}\right)$ & 30 & 50 & 60 & 100 & 80 & 60 & 90 & 60 & 110 & 80 & 40 & 60 & 50 & 50 \\
\hline Silt $\left(\mathrm{g} \mathrm{kg}^{-1}\right)$ & 270 & 0 & 0 & 0 & 180 & 0 & 0 & 0 & 350 & 00 & 200 & 140 & 150 & 100 \\
\hline Clay $\left(\mathrm{g} \mathrm{kg}^{-1}\right)$ & 680 & 700 & 680 & 630 & 670 & 750 & 490 & 670 & 450 & 640 & 440 & 730 & 690 & 790 \\
\hline
\end{tabular}

(1) Organic carbon; ${ }^{(2)}$ Prem: remaining $\mathrm{P}$; ${ }^{(3)}$ Saturation by $\mathrm{Al}^{3+} ;{ }^{(4)}$ Sum of bases; ${ }^{(5)}$ Bases saturation; ${ }^{(6)} \mathrm{Molar}$ ratio $\left(\mathrm{SiO}_{2} / \mathrm{Al}_{2} \mathrm{O}_{3} \times\right.$ 1.7) obtained by sulphuric digestion; (7) Molar ratio $\left[\mathrm{SiO}_{2} \times 1.7 /\left(\mathrm{Al}_{2} \mathrm{O}_{3}+0.64 \times \mathrm{Fe}_{2} \mathrm{O}_{3}\right)\right]$ obtained by sulphuric digestion.

solution with resin was determined by colorimetry, according to Braga and Defelipo (1974).

For $\mathrm{P}$ determination in the soil by extractant $\mathrm{M}-1,2.5 \mathrm{~cm}^{3}$ of ADFE were placed in $50 \mathrm{~mL}$ centrifuge tubes with $25 \mathrm{~mL}$ extractant. The mixtures were shaken vertically (Wagner agitator, $50 \mathrm{rpm} / 5 \mathrm{~min}$ ), and after $16 \mathrm{~h}$ of sedimentation, aliquots of supernatants were removed to determine P contents (Braga and Defelipo, 1974).

To compose the correlation matrix of mineralogical properties, minerals of the clay fraction were estimated by allocation, according to the method proposed by Resende et al. (1987), using software ALOCA (Moura Filho et al., 1995). Therefore, the chemical elements of the minerals extracted by sulphuric digestion and citrate-bicarbonate-dithionite (CBD) in clay fraction were allocated to the minerals identified by X-ray diffraction (XRD). By calculating the average size of crystal from the half-height width of reflections (104), (110) and (012) of hematite $(\mathrm{Hm})$ and (110) and (111) of goethite (Gt) by the Scherrer equation (Klug and Alexander,
1954), we determined the values of the specific surface area (SSA) for the respective minerals, considering the geometric shape of a sphere for Gt (Schwertmann and Kämpf, 1985) and circular plates (geometric shape of a cylinder) for $\mathrm{Hm}$ (Schwertmann et al., 1979; Melo et al., 2001). Isomorphous substitution (IS) of $\mathrm{Fe}^{3+}$ by $\mathrm{Al}^{3+}$ in the $\mathrm{Hm}$ and Gt structure was estimated by the position of reflections of these minerals obtained by XRD, using silicon as an internal standard for offset correction. In Gt, IS was calculated from the equation proposed by Schulze (1984) and, in Hm as in Schwertmann et al. (1979). The relationship $\mathrm{Hm} /(\mathrm{Hm}+\mathrm{Gt})$ was estimated based on the areas of reflections concerning the plan (012) of $\mathrm{Hm}$ and (110) of Gt. The formula used to calculate was proposed by Resende et al. (1987): $\mathrm{Hm} /(\mathrm{Hm}+\mathrm{Gt})=4 \times(\mathrm{Hm} 012) / 4 \times \mathrm{A}(\mathrm{Hm} 012)+\mathrm{A}(\mathrm{Gt110})$.

Samples of ADFE were also subjected to five successive extractions with CBD (Mehra and Jackson, 1960) before and after 10 successive $P$ extractions with M-1 and IER and a single extraction with ammonium acid oxalate (AAO) (McKeague 
and Day, 1966). The contents of $\mathrm{Fe}$ and $\mathrm{Al}$ were determined by atomic absorption spectrophotometry.

\section{RESULTS AND DISCUSSION}

We observed a wide range of contents of total $\mathrm{Ca}$ $\left(\mathrm{Ca}_{\mathrm{T}}\right)\left(29\right.$ to $\left.1,554 \mathrm{mg} \mathrm{kg}^{-1}\right)$ and total $\mathrm{P}\left(\mathrm{P}_{\mathrm{T}}\right)(810$ to $11,211 \mathrm{mg} \mathrm{kg}^{-1}$ ) in the soils studied (Table 2). Even in the case of highly weathered soils as the Latosols, the Ca total contents found were higher than those observed by Rolim Neto et al. (2009) in Latossolos Vermelhos of two topolito sequences in the Alto Paranaíba region. Higher $\mathrm{Ca}_{\mathrm{T}}$ and $\mathrm{P}_{\mathrm{T}}$ contents were observed in tuffite-derived soils, particularly in the samples $\mathrm{LV}_{6}, \mathrm{LV}_{7}, \mathrm{LV}_{8}, \mathrm{LV}_{9}$, and $\mathrm{LV}_{10}$, possibly a result of contributions of $\mathrm{P}$ forms linked to $\mathrm{Ca}$ (P-Ca) related to the mineralogy of mafic/ultramafic bodies in the Alto Paranaíba region (Barbosa et al., 1970; Rolim Neto et al., 2009). In addition, the positive correlation $\left(\mathrm{r}=0.98^{* *}\right)$ between $\mathrm{Ca}_{\mathrm{T}}$ and $\mathrm{P}_{\mathrm{T}}$ contents underscores the influence of $\mathrm{P}-\mathrm{Ca}$ forms on $\mathrm{P}$ contents in the soil (Table 3 ).

The contents of total $\mathrm{Fe}\left(\mathrm{Fe}_{\mathrm{T}}\right)$ ranged from 111 to $377 \mathrm{~g} \mathrm{~kg}^{-1}$, and were highest in $\mathrm{LV}_{11}$, formed from itabirite. Conversely, the $\mathrm{Al}$ content extracted by total digestion $\left(\mathrm{Al}_{\mathrm{T}}\right)$ from the same soil was lowest. The significant correlation $\left(r=-0.78^{* *}\right)$ between $\mathrm{Fe}_{\mathrm{T}}$ and $\mathrm{Al}_{\mathrm{T}}$ in the soils studied reflects proportionality of these elements in parent materials (Table 3). Due to the greater sensitivity of iron oxides to oxidation-reduction procedures, they can be solubilized in humid soil environments by the reduction of $\mathrm{Fe}^{3+}$ in the structure of pedogenetic $\mathrm{Fe}$ oxides, to the easily leachable $\mathrm{Fe}^{2+}$ (soluble phase). Therefore, reductions in the $\mathrm{Fe}_{\mathrm{T}} / \mathrm{Al}_{\mathrm{T}}$ ratio in soils could also be linked to this phenomenon, for example, in $\mathrm{LVA}_{1}$ samples.

The absence of a significant correlation $\left(\mathrm{r}=0.28^{\mathrm{n} . \mathrm{s}}\right)$ between $\mathrm{Fe}_{\mathrm{T}}$ and $\mathrm{P}_{\mathrm{T}}$ contents (Table 3), suggests that $\mathrm{P}_{\mathrm{T}}$ contents in soils are not related to $\mathrm{Fe}$-associated $\mathrm{P}$ forms, as the forms linked to $\mathrm{Hm}$ and $\mathrm{Gt}$, whose effect on $\mathrm{P}$ sorption is well-documented in the literature (Ker, 1995; Fontes and Weed, 1996; Rolim Neto et al., 2004).

The significant correlation between $\mathrm{Al}_{\mathrm{T}}$ contents and $\mathrm{Ca}_{\mathrm{T}}\left(\mathrm{r}=-0.59^{*}\right)$ and $\mathrm{P}_{\mathrm{T}}\left(\mathrm{r}=-0.60^{*}\right)$ contents suggests the reduction of $\mathrm{Ca}$ and $\mathrm{P}$ contents with loss of bases and anions, respectively, throughout the alitization process of soils, as well as the possible occurrence of apatites altered with considerable $\mathrm{Al}$ contents replacing $\mathrm{Ca}$ or $\mathrm{P}$ in their structure, as reported by Rolim Neto (2002) based on micromorphological and microchemistry analyses in Cambiosols in the Alto Paranaíba region. Al can replace $\mathrm{Ca}^{2+}$, in the form of $\mathrm{Al}^{3+}$, and phosphate $\left(\mathrm{PO}_{4}^{3-}\right)$ (rarely), in the form of $\mathrm{AlO}_{2}$, in the structure of apatites. These crystallochemical modifications can cause variations in solubility, reactivity, crystallinity
Table 2. Total contents of calcium $\left(\mathrm{Ca}_{\mathrm{T}}\right)$, phosphorus $\left(\mathrm{P}_{\mathrm{T}}\right)$, iron $\left(\mathrm{Fe}_{\mathrm{T}}\right)$, aluminum $\left(\mathrm{Al}_{\mathrm{T}}\right)$ and titanium $\left(\mathrm{Ti}_{\mathrm{T}}\right)$ in air-dried fine earth fraction of the $B$ horizonts of Latossolos Vermelhos ferric and perferric and Latossolo Vermelho-Amarelo mesoferric

\begin{tabular}{|c|c|c|c|c|c|}
\hline Profile & $\mathbf{C} \mathbf{a}_{\mathbf{T}}$ & $\mathbf{P}_{\mathrm{T}}$ & $\mathbf{F e}_{\mathbf{T}}$ & $\mathrm{Al}_{\mathrm{T}}$ & $\mathbf{T i}_{\mathbf{T}}$ \\
\hline & \multicolumn{2}{|c|}{$\mathrm{mg} \mathrm{kg}^{-1}$} & \multicolumn{3}{|c|}{$\mathrm{g} \mathrm{kg}^{-1}$} \\
\hline $\mathrm{LV}_{1}$ & 147.3 & 1257.7 & 209.5 & 121.4 & 45.3 \\
\hline $\mathrm{LV}_{2}$ & 29.6 & 1516.3 & 211.7 & 151.8 & 41.6 \\
\hline $\mathrm{LV}_{3}$ & 112.0 & 1315.9 & 216.6 & 147.2 & 46.9 \\
\hline $\mathrm{LV}_{4}$ & 84.7 & 1861.5 & 216.7 & 143.3 & 43.2 \\
\hline $\mathrm{LV}_{5}$ & 87.0 & 1700.4 & 186.8 & 169.7 & 54.1 \\
\hline $\mathrm{LV}_{6}$ & 231.7 & 4212.4 & 133.6 & 126.3 & 56.1 \\
\hline $\mathrm{LV}_{7}$ & 709.6 & 6842.5 & 278.5 & 97.4 & 88.4 \\
\hline $\mathrm{LV}_{8}$ & 477.5 & 4669.0 & 224.7 & 125.7 & 71.8 \\
\hline $\mathrm{LV}_{9}$ & 1554.4 & 11211.0 & 259.1 & 82.6 & 87.6 \\
\hline $\mathrm{LV}_{10}$ & 628.0 & 6043.3 & 205.4 & 98.4 & 71.4 \\
\hline $\mathrm{LV}_{11}$ & 161.3 & 2041.7 & 377.1 & 67.1 & 15.6 \\
\hline $\mathrm{LV}_{12}$ & 52.7 & 1141.5 & 186.7 & 123.3 & 20.4 \\
\hline $\mathrm{LV}_{13}$ & 37.8 & 810.0 & 176.3 & 159.7 & 10.1 \\
\hline $\mathrm{LVA}_{1}$ & 73.8 & 1431.2 & 111.0 & 201.6 & 49.5 \\
\hline
\end{tabular}

Table 3. Pearson's correlation matrix between the total main elements (calcium - $\mathrm{Ca}_{\mathrm{T}}$, phosphorus $-\mathbf{P}_{\mathrm{T}}$, iron $-\mathrm{Fe}_{\mathrm{T}}$, aluminum $-\mathrm{Al}_{\mathrm{T}}$ and titanium - $\mathrm{Ti}_{\mathrm{T}}$ ) determined in air-dried fine earth fraction of the $B$ horizonts of Latossolos Vermelhos ferric and perferric and Latossolo Vermelho-Amarelo mesoferric

\begin{tabular}{llcccc}
\hline & $\mathbf{C} \mathbf{a}_{\mathbf{T}}$ & $\mathbf{P}_{\mathbf{T}}$ & $\mathbf{F e}_{\mathbf{T}}$ & $\mathbf{A l}_{\mathbf{T}}$ & $\mathbf{T i}_{\mathbf{T}}$ \\
\hline $\mathrm{Ca}_{\mathrm{T}}$ & 1.00 & & & & \\
$\mathrm{P}_{\mathrm{T}}$ & $0.98^{* *}$ & 1.00 & & & \\
$\mathrm{Fe}_{\mathrm{T}}$ & 0.32 & 0.28 & 1.00 & & \\
$\mathrm{Al}_{\mathrm{T}}$ & $-0.59^{*}$ & $-0.60^{*}$ & $-0.78^{* *}$ & 1.00 & \\
$\mathrm{Ti}_{\mathrm{T}}$ & $0.75^{* *}$ & $0.81^{* *}$ & 0.02 & -0.25 & 1.00 \\
\hline
\end{tabular}

$*$ and $* *$ : significance of 1 and $5 \%$, respectively.

and thermal stability (Toledo and Pereira, 2001). Although part of $\mathrm{Al}_{\mathrm{T}}$ is associated with the presence of aluminosilicate minerals, low $\mathrm{Ki}$ index values $\left(<0.75\right.$, except in $\left.L_{1}\right)$ (Table 1$)$, which indicate the predominance of oxide mineralogy in soils, suggest that the negative correlation between $\mathrm{Al}_{\mathrm{T}}$ and $\mathrm{P}_{\mathrm{T}}$ contents also resulted from the lack of influence of $\mathrm{P}$ forms linked to $\mathrm{Al}$, mainly those associated to gibbsite, with a strong effect on the process of $\mathrm{P}$ sorption (Ker, 1995; Rolim Neto et al., 2004).

The high content of total $\mathrm{Ti}\left(\mathrm{Ti}_{\mathrm{T}}\right)$ in soils confirms findings of increased contents of this element in soils developed on mafic rocks (Table 2) (Curi and 
Franzmeier, 1987; Rolim Neto et al., 2009). The incidence of increased $\mathrm{Ti}$ levels in tuffite-derived soils $\left(\mathrm{LV}_{5}, \mathrm{LV}_{6}, \mathrm{LV}_{7}, \mathrm{LV}_{8}, \mathrm{LV}_{9}\right.$, and $\left.\mathrm{LV}_{10}\right)$, or under its influence $\left(\mathrm{LVA}_{1}\right)$, is related to the higher residual content of anatase and to the significant presence of titanomagnetite and titanomaghemite in these soils (Fabris et al., 1994, 1997a,b). The significant correlations between contents of $\mathrm{Ti}_{\mathrm{T}}$ and $\mathrm{Ca}_{\mathrm{T}}\left(\mathrm{r}=0.75^{* *}\right)$, as well as contents of $\mathrm{Ti}_{\mathrm{T}}$ and $\mathrm{P}_{\mathrm{T}}$ $\left(r=0.81^{* *}\right)$, suggest the possibility of using Ti as an indicator of the contents of these elements in soils formed on mafic rocks.

After sequential extractions with M-1 ( $\left.\mathrm{P}_{\mathrm{M}-1}\right)$ and IER $\left(\mathrm{P}_{\text {IER }}\right), \mathrm{P}$ contents ranged from 6 to $439 \mathrm{mg} \mathrm{dm}^{-3}$ and from 14 to $441 \mathrm{mg} \mathrm{dm}^{-3}$, respectively (Figure 1). As observed for $\mathrm{P}_{\mathrm{T}}$ contents, in soils formed on tuffite, mainly in $\mathrm{LV}_{6}, \mathrm{LV}_{7}, \mathrm{LV}_{8}, \mathrm{LV}_{9}$, and $\mathrm{LV}_{10}$, the $\mathrm{P}_{\mathrm{M}-1}$ and $\mathrm{P}_{\text {IER }}$ values were highest, which reflects the importance of this parent material for $\mathrm{P}$ content in these soils. However, the nature of tuffite formation, as well as its mixture with other detrital (recycling) material, allows for great variation in the vertical and horizontal chemical composition of soils, justifying the low $\mathrm{P}_{\mathrm{M}-1}$ and $\mathrm{P}_{\mathrm{IER}}$ contents in other samples from tuffite formations $\left(\mathrm{LV}_{5}\right.$ and $\left.\mathrm{LVA}_{1}\right)$. According to Guimarães (1955), tuffite are basic, non-hardened rocks composed of mixtures of pyroclastic debris and volcanic ash, with high contents of $\mathrm{Fe}, \mathrm{K}, \mathrm{Ca}$ and $\mathrm{P}$.

Rolim Neto et al. (2009) found, in a single extraction, low contents of $\mathrm{P}_{\mathrm{M}-1}$ for Latossolos Vermelhos developed on mafic/ultramafic rocks in the Alto Paranaíba region and suggested the possibility of $\mathrm{P}$ translocation to less soluble forms in acidic medium such as those associated with $\mathrm{Fe}$ oxides and crystalline $\mathrm{Al}$, with the pedogenetic development of the soil.

The significant correlations between the $\mathrm{Ca}_{\mathrm{T}}$ and $\mathrm{P}_{\mathrm{M}-1}$ contents $\left(\mathrm{r}=0.96^{* *}\right)$ and $\mathrm{P}_{\mathrm{IER}}\left(\mathrm{r}=0.97^{* *}\right)$ deserve greater attention (Table 4). These correlations confirmed the existence of $\mathrm{P}$ forms linked to $\mathrm{Ca}$ in Latossolos Vermelhos, especially in those developed from tuffite formations in the Alto do Paranaíba region, and highlight the importance of these forms for native $\mathrm{P}$ content in the soil. In addition, the similarity found between $\mathrm{P}$ contents accumulated after sequential extractions with M-1 and IER, in most tuffite-derived soils also corroborated the predominant occurrence of $\mathrm{P}-\mathrm{Ca}$ in these soils. Also, the similarity between extractants M-1 and IER represents an additional $\mathrm{Ca}^{2+}$ drain, causing more effective solubilization of P-Ca (Figure 1) (Souza Júnior et al., 2012; Freitas et al., 2013). The absence of significant correlations between $\mathrm{P}$ extracted by M-1 and IER and crystallographic attributes (IS and SSA) for $\mathrm{Gt}$ and $\mathrm{Hm}$, as well as with the ratio $\mathrm{Hm} / \mathrm{Hm}+\mathrm{Gt}$ and some minerals of the clay fraction, aside from confirming the predominance of the P-Ca form in soils, also reflects the importance of the parent material in the soil mineralogical behavior for P (Table 4). (a)

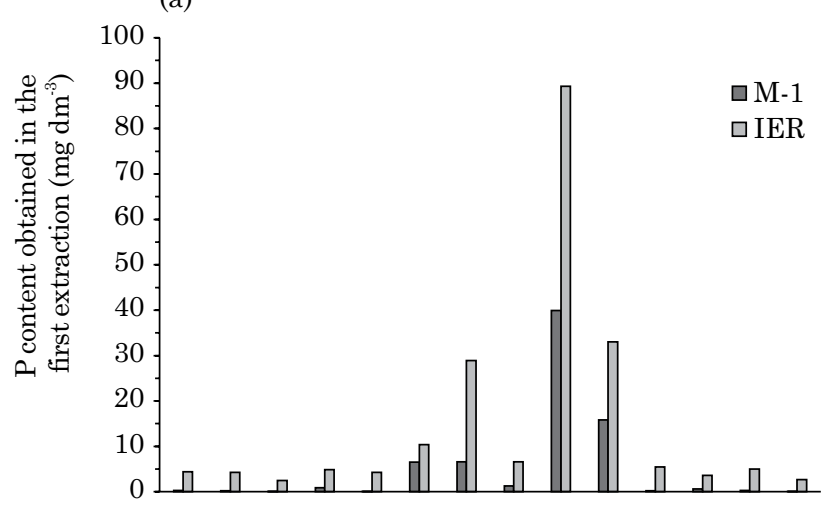

(b)

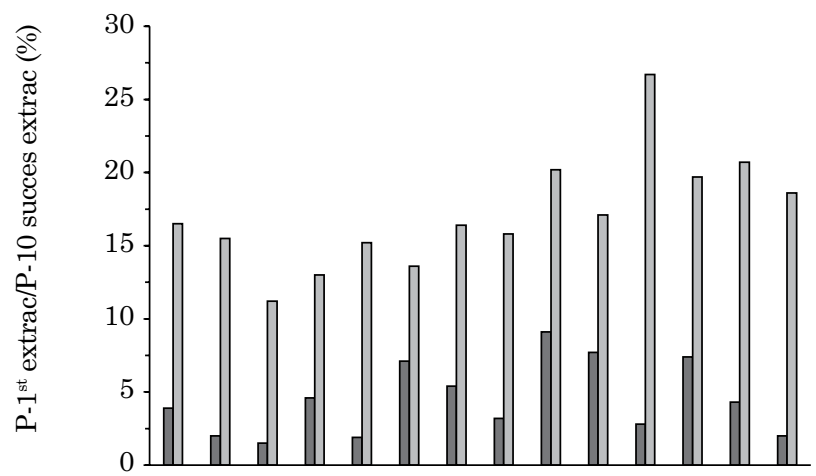

(c)

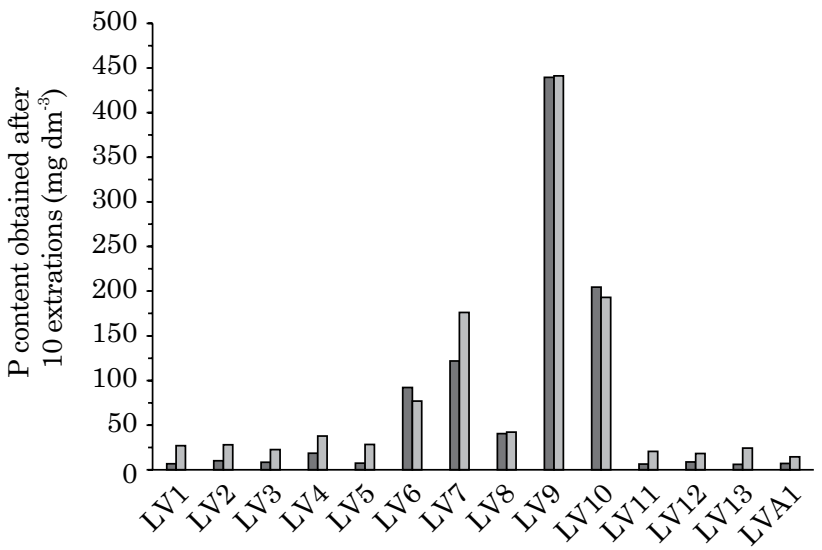

Figure 1. Phosphorus content obtained in the first extraction - P-1 ${ }^{\text {st }}$ extraction (a), relation between $P$ extracted in the first extraction and the $P$ extracted in 10 successive extractions $-P-1^{\text {st }}$ extrac/P-10 succes extrac (b), and $P$ content after 10 successive extractions (c) with extractants Mehlich-1 (M-1) and ion exchange resin (IER) of the B horizonts of Latossolos Vermelhos ferric and perferric and Latossolo Vermelho-Amarelo mesoferric.

Motta et al. (2002) studied P forms in surface horizons of Latosols of cultivated and non-cultivated systems and found higher values for the ratio 
Table 4. Pearson's correlation matrix between contents of $P$ accumulated after 10 successive extractions with Mehlich-1 ( $\left.P_{M-1}\right)$ and ion exchange resin $\left(P_{I E R}\right)$, and minerals of kaolinite clay fraction $(C t)$, goethite (Gt), hematite $(\mathrm{Hm})$ and gibbsite $(\mathrm{Gb})$, the specific surface area of Gt $\left(\mathrm{SSA}_{\mathrm{Gt}}\right)$ and $\mathrm{Hm}\left(\mathrm{SSA}_{\mathrm{Hm}}\right)$, isomorphous substitution of $\mathrm{Fe}^{3+}$ for $\mathrm{Al}^{3+}$ in $\mathrm{Gt}\left(\mathrm{IS}_{\mathrm{Gt}}\right)$ and $\mathrm{Hm}\left(\mathrm{IS}_{\mathrm{Hm}}\right)$, the ratio $\mathrm{Hm} / \mathrm{Hm}+\mathrm{Gt}$ and content of $\mathrm{Ca}\left(\mathrm{Ca}_{\mathrm{T}}\right)$ obtained by total digestion of air-dried fine earth ${ }^{(1)}$ of the B horizonts of Latossolos Vermelhos ferric and perferric and Latossolo Vermelho-Amarelo mesoferric

\begin{tabular}{ccccccccccc}
\hline & $\mathbf{C t}$ & $\mathbf{G t}$ & $\mathbf{H m}$ & $\mathbf{G b}$ & $\mathbf{H m} / \mathbf{H m}+\mathbf{G t}$ & $\mathbf{S S A}_{\mathbf{G t}}$ & $\mathbf{S S A}_{\mathbf{H m}}$ & $\mathbf{I S}_{\mathbf{G t}}$ & $\mathbf{I S}_{\mathbf{H m}}$ & $\mathbf{C a}_{\mathbf{T}}$ \\
\hline $\mathrm{P}_{\mathrm{M}-1}$ & -0.33 & -0.35 & -0.39 & -0.28 & 0.50 & -0.32 & 0.51 & -0.33 & 0.22 & $0.96^{* *}$ \\
$\mathrm{P}_{\text {IER }}$ & -0.37 & -0.41 & -0.41 & -0.028 & 0.52 & -0.19 & 0.45 & 0.20 & 0.20 & $0.97^{* *}$ \\
\hline$* *$ : significant at 1 \%. ${ }^{(1)}$ Minerals of the clay fraction estimated by the allocation method of Resende et al. (1987).
\end{tabular}

$\mathrm{P}-\mathrm{Ca} /(\mathrm{P}-\mathrm{Al}+\mathrm{P}-\mathrm{Fe})$ in an acric Latossolo Vermelho under cultivation, developed on fine tertiary sediments that cover the plateaus of Central Brazil, as well as in cultivated and non-cultivated dystroferric Latossolos Vermelhos, developed on tuffite. In the first case, the author attributed the results to liming and heavy phosphate fertilization over the years, because soils with such high contents of available $\mathrm{P}$ are rare in Brazil. In the second case, the original $P$ richness of the soil could explain the few variations in contents between cultivated and non-cultivated soils. Corroborating the findings of Motta et al. (2002), in sample $\mathrm{LV}_{6}$, from an area under native forest, the $\mathrm{P}$ contents were attributed to the contribution of the parent material (tuffite). However, in the samples $\mathrm{LV}_{7}, \mathrm{LV}_{9}$ and $\mathrm{LV}_{10}$ from cultivated systems, the contributions of liming and phosphate fertilization during the growing cycle possibly increased $\mathrm{P}$ contents in these soils.

Intriguingly, in this study, higher $\mathrm{P}$ contents were found in soils with long history of cultivation, leading to questions about $\mathrm{P}$ mobility in Latosols, known to be low (Nancy and Smyth, 1999; Donagemma et al., 2008). It is a consensus in the scientific community that Latosols are soils in advanced weathering stages and their formation involves both geochemical and biological processes. Perhaps, analyses of the effects of bioturbation on $\mathrm{P}$ mobility in oxidic Latosols, especially of the Fe-rich, could be added, because the consequences for textural and mineralogical homogenization are already known (Ferreira et al., 2011; Resende et al., 2014). According to Lee and Wood (1971), soil accumulation rates due to termite action can vary between 0.05 and $0.4 \mathrm{~mm}_{\text {year }}{ }^{-1}$.

Another important aspect was the $\mathrm{P}$ rate obtained from the first extraction in relation to total $\mathrm{P}$ after all sequential extractions with M-1 and IER (Figure 1). The ratios ranged from 1.5 to $9.1 \%$ and from 11.2 to $26.7 \%$ after extractions with M-1 and IER, respectively. We observed that $\mathrm{P}_{\text {IER }}$ contents in the first extraction were higher than for $\mathrm{P}_{\mathrm{M}-1}$ in all soils. This corroborates findings of Gatiboni et al. (2002) in dystrophic Latossolos Vermelhos samples with low contents of available $\mathrm{P}$ and with a greater capacity of IER to extract labile $\mathrm{P}$, regardless of soil buffering, because it is not abrasive under these conditions, in contrast to M-1 (Silva and Raij, 1999; Simões Neto et al. 2009). However, in weathered soils, the potentially available $\mathrm{P}$ is underestimated because successive extractions with the same extractant remove $\mathrm{P}$ from the soil continously (Campello et al., 1994; McKean and Warren, 1996; Rheinheimer et al., 2000; Gatiboni et al., 2002; Rheinheimer et al., 2003).

The sensitivity effect (wear) of extractant M-1 in highly buffered soils could be clearly observed in tuffite-derived soils, especially in samples $\mathrm{LV}_{7}, \mathrm{LV}_{9}$ and $\mathrm{LV}_{10}$, whose $\mathrm{P}$ contents determined by IER were roughly twice those extracted by M-1 after a single extraction. Given the possibility of greater influence of $\mathrm{P}$-Ca in these soils, aside from the effect of $\mathrm{P}$ drain of the anionic resin, the strong action of $\mathrm{Ca}$ drain of the cationic resin intensifying $\mathrm{P}$ solubilization (Souza Júnior et al., 2102; Freitas et al., 2013) led to a greater $\mathrm{P}$ removal by IER than by extractant M-1, which had a limited extraction potential, due to the sensitivity effect.

Wide variations were not observed between contents of $\mathrm{Fe}_{2} \mathrm{O}_{3}$ and $\mathrm{Al}_{2} \mathrm{O}_{3}$ obtained by $\mathrm{CBD}$ and $\mathrm{AAO}$ in samples after sequential $\mathrm{P}$ extractions with M-1 and IER and samples not subjected to $\mathrm{P}$ extractions, indicating an inexpressive effect of $\mathrm{P}$ extractants on $\mathrm{Fe}$ oxyhydroxide minerals over successive extractions (Figure 2). Therefore, the reaction of acidic ligand anion exchange $\left(\mathrm{PO}_{4}^{3-}\right.$ for $\mathrm{SO}_{4}^{2}$ ) in inorganic colloidal particles of soil samples under extractions with M-1 (Nancy et al., 2007) and the exchange reaction by difference of electrostatic ionic concentration of the solid phase with the soil solution samples when extracted with IER (Silva and Raij, 1999), do not significantly change the contents of Fe oxyhydroxide minerals in Latosols.

Significant correlations between the content of $\mathrm{Fe}_{2} \mathrm{O}_{3}$ extracted by $\mathrm{AAO}$ in samples without $\mathrm{P}$ extraction and the contents of $\mathrm{P}_{\mathrm{M}-1}\left(\mathrm{r}=0.79^{* *}\right)$ and $\mathrm{P}_{\text {IER }}\left(\mathrm{r}=0.81^{* *}\right)$, along with the slightly lower values of $\mathrm{Al}_{2} \mathrm{O}_{3}$ in soil samples after sequential $\mathrm{P}$ extractions by M-1 and IER (Figure 2), reflect the possible participation of forms of $\mathrm{Fe}$ and $\mathrm{Al}$ oxyhydroxide minerals of low crystallinity in P content of soils, as observed by Fontes and Weed (1996). 

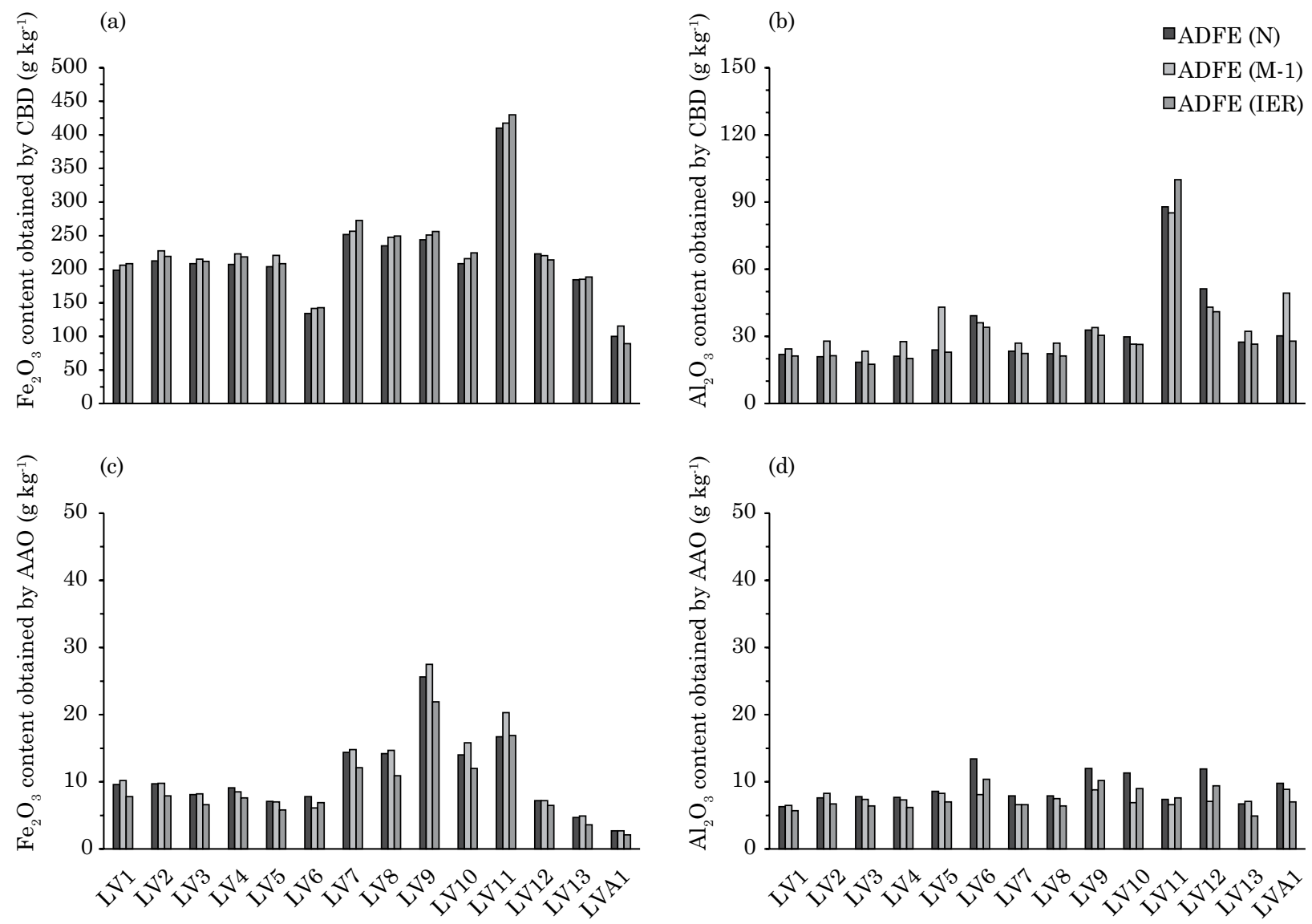

Figure 2. $\mathrm{Fe}_{2} \mathrm{O}_{3}$ (a) and $\mathrm{Al}_{2} \mathrm{O}_{3}$ (b) contents obtained by successive extractions with citrate-bicarbonate-dithionite (CBD); $\mathrm{Fe}_{2} \mathrm{O}_{3}$ (c) and $\mathrm{Al}_{2} \mathrm{O}_{3}$ (d) contents obtained by single extraction with acid ammonium oxalate $(A A O)$ in air-dried fine earth (ADFE) samples, before $\left(\mathrm{ADFE}_{(\mathrm{N})}\right)$ and after 10 sequential extractions with Mehlich-1 $\left(\mathrm{ADFE}_{(\mathrm{M}-1)}\right)$ and ion exchange resin $\left(\mathrm{ADFE}_{(\mathrm{IER})}\right)$ of the $\mathrm{B}$ horizonts of Latossolos Vermelhos ferric and perferric and Latossolo Vermelho-Amarelo mesoferric.

\section{CONCLUSIONS}

The higher contents of total $\mathrm{P}$ in tuffite-derived soils show strong contribution of this rock to the $\mathrm{P}$ pool in these soils.

The highly significant correlations observed between the contents of total $\mathrm{Ca}$ and $\mathrm{P}$ extracted by Mehlich-1 (M-1) and by ion-exchange resin (IER) indicate pronounced influence of P-Ca in soils, particularly in Latossolos Vermelhos formed on tuffite in the Alto Paranaíba region.

Ion-exchange resin was more efficient to determine $\mathrm{P}$ availability, for removing larger amounts in the first extraction in all soils.

A single extraction with M-1 or IER is not sufficient to estimate the amount factor of $\mathrm{P}$ in highly weathered soils, such as Latosols, because successive extractions with the same extractant continously remove $\mathrm{P}$ from the soil, as reported in the literature.

\section{ACKNOWLEDGEMENTS}

The authors wish to thank Coordenação de Aperfeiçoamento de Pessoal de Nível Superior (CAPES) for the financial support. We also thank Irio Fernando de Freitas M.Sc. for his assistance with the chemical extractions.

\section{REFERENCES}

Alvarez V, VH, Novais RF, Dias LE, Oliveira JA. Determinação e uso do fósforo remanescente. B Inf Soc Bras Ci Solo. 2000;52:27-32

Bahia Filho AFC, Braga JM, Ribeiro AC, Novais RF. Sensibilidade de extratores químicos à capacidade tampão de fósforo. $\mathrm{R}$ Bras Ci Solo. 1983;7:243-9.

Barbosa O, Braun OPG, Dyer RC, Cunha CABR. Geologia da Região do Triângulo Mineiro. Rio de Janeiro: DNPM/DFPM; 1970. (Boletim, 136). 
Braga JM, Defelipo BV. Determinação espectrofotométrica de fósforo em extratos de solo e material vegetal. $\mathrm{R}$ Ceres. 1974;21:73-85.

Campello MR, Novais RF, Fernandez IE, Fontes MPF, Barros NF. Avaliação da reversibilidade de fósforo não-lábil para lábil em solos com diferentes características. R Bras Ci Solo. 1994;18:157-65.

Curi N, Franzmeier DP. Effect of parent rocks on chemical and mineralogical properties of some Oxisols in Brazil. Soil Sci Soc Am J. 1987;51:153-8.

Donagemma GK, Ruiz HA, Alvarez V VH, Ferreira PA, Cantarutti RB, Silva AT, Coutinho G. Distribuição do amônio, nitrato, potássio e fósforo em colunas de Latossolos fertirrigadas. R Bras Ci Solo. 2008;32:2493-504.

Empresa Brasileira de Pesquisa Agropecuária - Embrapa. Centro Nacional de Pesquisa de Solos. Manual de métodos de análise de solos. Dados eletrônicos. $2^{\mathrm{a}}$.ed. Rio de Janeiro: Embrapa Solos; 2011.

Fabris JD, Coey JMD, Jesus Filho MF, Santana DP, Goulart AT, Fontes MPF, Curi N. Mineralogical analysis of a weathering mantle derived from tuffite. Hyper Interac. 1994;91:751-7.

Fabris JD, Jesus Filho MF, Mussel WN, Coey JMD, Goulart AT. Iron-rich spinels from Brazilian soils. Hyper Interac. 1997a; 110:23-32.

Fabris JD, Mussel WN, Coey JMD, Jesus Filho MF, Goulart AT. Mg-rich iron oxide spinels from tuffite. Hyper Interac. 1997b;10:33-40.

Ferreira EVO, Martins V, Inda Junior AV, Giasson E, Nascimento PC. Ação das térmitas no solo. Ci Rural. 2011;41:804-11.

Fontes MPF, Weed SB. Phosphate adsorption by clays from Brazilian Oxisoils: relationships with specific surface area and mineralogy. Geoderma. 1996;72:37-51.

Freitas IF, Novais RF, Villani EMA, Novais SV. Phosphorus extracted by ion exchange resins and Mehlich-1 from Oxisols (Latosols) treated with different phosphorus rates and sources for varied soil-source contact periods. R Bras Ci Solo. 2013;37:667-77.

Gatiboni LC, Kaminski J, Rheinheimer DS, Saggin A. Quantificação do fósforo disponível por extrações sucessivas com diferentes extratores em Latossolo Vermelho distroférrico. R Bras Ci Solo. 2002;26:1023-9.

Guimarães D. Contribuição ao estudo dos tufos vulcânicos da Mata da Corda. Belo Horizonte: Instituto de Tecnologia Industrial; 1955. (Boletim, 18).

Ker JC. Mineralogia, sorção e dessorção de fosfatos, magnetização e elementos traços de Latossolos do Brasil [tese]. Viçosa, MG: Universidade Federal de Viçosa; 1995.

Lee KE, Wood TG. Termites and soils. London and New York: Academic Press; 1971.

Mckeague JA, Day JH. Dithionite and oxalate-extractable Fe and $\mathrm{Al}$ as aids in differentiating various classes of soils. Can J Soil Sci. 1966;46:13-22.

Mckean SJ, Warren GP. Determination of phosphate desorption characteristics in soils using successive resin extractions. Commun Soil Sci Plant Anal. 1996;27:2397-417.

Mehra JP, Jackson ML. Iron oxides removal from soils and clays by a dithionite-citrate-bicarbonate system buffered with bicarbonate sodium. Clays Clay Miner. 1960;7:317-27.
Melo VF, Fontes MPF, Novais RF, Singh B, Schaefer CEGR. Características dos óxidos de ferro e de alumínio de diferentes classes de solos. R Bras Ci Solo. 2001;25:19-32.

Motta PEF, Curi N, Siqueira JO, Raij Bvan, Furtini Neto AE, Lima JM. Adsorção e formas de fósforo em Latossolos: influência da mineralogia e histórico de uso. R Bras Ci Solo. 2002;26:349-59.

Moura Filho G, Resende M, Cruz CD. ALOCA - Programa de estimativa de minerais do solo. Versão 1.0. [Software] In: Anais do $25^{\circ}$. Congresso Brasileiro da Ciência do Solo; Viçosa, MG; 1995. Viçosa, MG: Sociedade Brasileira de Ciência do Solo; 1995.

Novais RF, Smyth TJ, Nunes FN. Fósforo. In: Novais RF, Alvarez V VH, Barros NF, Fontes RLF, Cantarutti RB, Neves JCL, editores. Fertilidade do solo. Viçosa, MG: Sociedade Brasileira de Ciência do Solo; 2007. p.471-550.

Novais RF, Smyth TJ. Fósforo em solo e planta em condições tropicais. Viçosa, MG: Universidade Federal de Viçosa; 1999.

Raij Bvan, Quaggio JA. Determinação de fósforo, cálcio, magnésio e potássio extraídos com resina trocadora de íons. In: Raij Bvan, Andrade JC, Cantarella H, Quaggio JA, editores. Análise química para avaliação da fertilidade de solos tropicais. Campinas: Secretaria de Agricultura e Abastecimento, APTA/ IAC; 2001. p.189-99.

Raij Bvan. Fertilidade do solo e adubação. Piracicaba: Ceres; 1991.

Resende M, Bahia Filho AFC, Braga JM. Mineralogia da argila de Latossolos estimada por alocação a partir do teor total de óxidos do ataque sulfúrico. R Bras Ci Solo. 1987;11:17-23.

Resende M, Curi N, Resende SB, Corrêa GF. Pedologia: base para distinção de ambientes. $6^{a}$.ed. Lavras: Universidade Federal de Lavras; 2014.

Rheinheimer DS, Anghinoni I, Conte E, Kaminski J, Gatiboni LC. Dessorção de fósforo avaliada por extrações sucessivas em amostras de solo provenientes dos sistemas plantio direto e convencional. Ci Rural. 2003;33:1053-9.

Rheinheimer DS, Anghinoni I, Kaminski J. Depleção do fósforo inorgânico de diferentes frações provocada pela extração sucessiva com resina em diferentes solos e manejos. $\mathrm{R}$ Bras $\mathrm{Ci}$ Solo. 2000;24:345-54.

Rolim Neto FC, Schaefer CEGR, Costa LV, Corrêa MM, Fernandes Filho EI, Ibraimo MM. Adsorção de fósforo, superfície específica e atributos mineralógicos em solos desenvolvidos de rochas vulcânicas do Alto Paranaíba (MG). R Bras Ci Solo. 2004;28:953-64.

Rolim Neto FC, Schaefer CEGR, Fernandes Filho EI, Corrêa MM, Costa LM, Parahyba RB, Guerra SMS, Heck R. Topolitossequências de solos de Alto Paranaíba: atributos físicos, químicos e mineralógicos. R Bras Ci Solo. 2009;33:1795-809.

Rolim Neto FC. Gênese, química, mineralogia e micromorfologia de topolitosequências de solos do Alto Paranaíba, MG [tese]. Viçosa, MG: Universidade Federal de Viçosa; 2002.

Schulze DG. The influence of aluminium on iron oxides. VIII - unit-cell dimensions of Al-substituted goethites and estimation of Al from them. Clays Clay Miner. 1984;32:36-44.

Schwertmann U, Fitzpatrick RW, Taylor RM, Lewis DG. The influence of aluminium on iron oxides. Part II. Preparation and properties of Al-substituted hematites. Clays Clay Miner. 1979;29:269-76. 
Schwertmann U, Kämpf N. Properties of goethite and hematite in kaolinitic soils of Southern and Central Brazil. Soil Sci. 1985; $139: 344-50$

Silva FC, Raij Bvan. Disponibilidade de fósforo em solos avaliada por diferentes extratores. Pesq Agropec Bras. 1999;34:267-88.

Simões Neto DE, Oliveira AC, Freire FJ, Freire MBGS, Nascimento CWA, Rocha AT. Extração de fósforo em solos cultivados com cana-de-açúcar e suas relações com a capacidade tampão. R Bras Eng Agríc Amb. 2009;13:840-8.
Souza Júnior RF, Oliveira ESF, Santos HC, Freire FJ, Arruda JA. Frações de fósforo inorgânico do solo e suas correlações com o fósforo quantificado por extratores e pelo milho. R Bras Ci Solo. 2012;36:159-69.

Toledo MCM, Pereira VP. A variabilidade de composição da apatita associada a carbonatitos. R Inst Geogr. 2001;22:27-64.

Valladares GS, Pereira MG, Anjos LHC. Adsorção de fósforo em solos de argila de atividade baixa. R Bras Ci Solo. $2003 ; 62: 111-8$ 